\title{
Design and Development of a Three-Stacked 12/8 Permanent-Magnet-Type Reluctance Generator
}

\author{
J. Yoshida, K. Nakamura, and O. Ichinokura \\ Graduate School of Engineering, Tohoku University, 6-6-05 Aoba Aramaki, Aoba-ku, Sendai, Miyagi 980-8579, Japan
}

\begin{abstract}
A permanent-magnet-type reluctance generator (PMRG) has a doubly salient pole structure. The permanent magnets are embedded in the stator yoke, and the concentrated windings are arranged individually around each stator pole. On the other hand, since the rotor has neither permanent magnets nor windings, the PMRG has a simple and robust structure, low cost, and high efficiency. Thus, it is suitable for wind-turbine generation and small-scale hydroelectric power generation. Although it has large torque ripple due to the salient pole structure, we have proposed a multi-stacked PMRG to reduce the torque ripple. This paper describes the design of a three-stacked 12/8 PMRG of $400 \mathrm{~W}$ by the finite element method (FEM). In addition, experimental results obtained with a trial generator are presented.
\end{abstract}

Key words: permanent-magnet-type reluctance generator (PMRG), multi-stacked, finite element method (FEM), wind-turbine generation

\section{3 段積み $12 / 8$ 永久磁石式リラクタンスジェネレータの設計・開発}

吉田 潤, 中村 健二, 一ノ倉 理

東北大学大学院工学研究科, 宮城県仙台市青葉区荒巻字青葉 6-6-05 ( $9980-8579)$

\section{1. はじめに}

地球温暖化の原因となる大気污染物質の削減，ならびに省エネ ルギー対策のため, 風力, 小水力, マイクロガスタービンなどの 分散型電源の導入が積極的に進められている. またこれに伴い, 小・中容量の発電機の需要が拡大しており, 小型, 高効率, 低コ スト化に対する要求が高まっている.

現在, 広く一般に用いられている発電機としては, 誘導発電機, 巻線形同期発電機, 永久磁石同期発電機などが挙げられる. これ らの発電機の特徵として, 誘導発電機は構造が簡単で堅牢, 電力 系統との連系が容易であるが，力率，効率が低いという久点があ る. 巻線形同期発電機は, 力率, 効率ともに高いが, スリップリ ングとブラシを有するため構造が複雑であり，小・中容量の発電 機には必ずしも適さない. 永久磁石同期発電機は, 界磁巻線やス リップリング, ブラシが不要なため, 保守性に優れ効率も高いが, 回転子に永久磁石を配置寸るため, 高速回転時の磁石の飛散や, 高温環境下での使用にやや難がある.

スイッチトリラクタンス (SR) モータを発電機として利用した SR ジェネレータは，固定子，回転子ともに突極構造を有し，巻線 は固定子極の夕に集中巻される. 回転子は鉄心のみで構成される ため, ブラシやスリップリングは不要である. 従って, SR ジェネ レータは構造が極めて簡単で堅牢, 高速回転に適する, 形状の自 由度が高いため多極機の製作が容易などの特長を有しており, 航 空機のスタータ/ジェネレータへの適用や(1), 風力発電への応用が 試みられている(2). しかしながら, SR ジェネレータは, 回転子位 置検出器や励磁用電源を必要とするため, 発電システムが複雑に なる問題があった.

これに対して筆者らは, SR ジェネレータの固定子ヨークに永久 磁石を配置し, 磁気回路の磁気抵抗変化によって, 巻線鎖交磁束 を周期的に変動させることで発電する, 永久磁石式リラクタンス
ジェネレータ (Permanent magnet type reluctance generator, 以下 PMRG と略記) を提案した (3). PMRG は, 永久磁石を固定 子ヨークに配置するため, 高速回転時の磁石飛散の問題が無く, また冷却も容易な構造であるため, 一般的な永久磁石同期発電機 と比べて，より高温の環境下でも使用できると考えられる. さら に, 回転子位置検出器や励磁用電源も不要であるため, 発電シス テムは極めて簡便になる. すでに, 定格回転数 $4800 \mathrm{rpm}$, 定格出 力 $500 \mathrm{~W}$ の 3 相 6/4 PMRG の試作を行っており，90\%以上の効 率が得られることを確認している(4). また, 先の研究では, 同一形 状の複数台の PMRG を, 固定子の空間的な位相をずらして重ねる ことにより, トルクリプルを低減できる可能性を, 簡易的にでは あるが PMRG の磁気回路モデルを用いて示した(5).

そこで本稿では，小型風力発電への応用を目的として，定格回 転数 $1000 \mathrm{rpm}$, 定格出力 $400 \mathrm{~W}$ の 3 段積夕 3 相 $12 / 8$ PMRG の 設計と基礎特性の試験を行ったので報告する.

\section{12/8PMRG の設計}

本稿で設計する PMRG の定格出力は, 3 段積みで 400 W $(1000$ rpm）であることから，1台当たりの出力は $400 \mathrm{~W}$ の $1 / 3$ である $133 \mathrm{~W}$ で良い，以下では，回転数 $1000 \mathrm{rpm}$ で $133 \mathrm{~W}$ を超える PMRGの設計を行う.

図 1 に，今回の設計の基になった現有のPMRG の諸元を示寸. 固定子は 6 極, 回転子は 4 極の 3 相機であり, 定格出力は $4800 \mathrm{rpm}$ で約 $560 \mathrm{~W}$ である. 磁心材質は厚さ $0.35 \mathrm{~mm}$ の無方向性ケイ素 鋼板であり，永久磁石は $\mathrm{Nd}-\mathrm{Fe}-\mathrm{B}$ である. 発電機の直径は 100 $\mathrm{mm}$, 積夕厚は $50 \mathrm{~mm}$ である.

図 2(a)は，3 次元有限要素法（3D-FEM）により算定した 6/4 PMRG の発電特性である. $P_{m}$ が機械入力, $P_{g}$ が発電機出力, $V_{o}$ が出力電圧， $\eta$ が銅損のみを考慮した場合の効率である. 同図(b) は，実機試験で得られた実測值である．これらの図を比較すると， 
実測值に対して3D-FEMの計算值は大きく見積もられていること がわかる. 例えば，最大出力を比較すると，3D-FEM では $638 \mathrm{~W}$

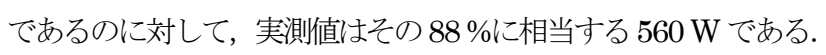
従って, FEM を用いて設計を行う際には，上記の誤差を考慮する 必要がある.

一般に発電機の出力は直径の 2 乗, 積从厚, そして回転 数に比例する. また, それらがすべて等しい場合でも, 多 極化によって出力が向上する可能性が, 先行研究により示 されている(6). 図 3 に, 2D-FEM で求めた同一体格, 同一 回転数での $6 / 4,12 / 8,18 / 12,24 / 18 \mathrm{PMRG}$ の出力電力の 計算值を示す.この図を見ると, $12 / 8$ PMRG の出力は, $6 / 4$ PMRG に対しておよそ 1.6 倍であることがわかる.また, 18/12 PMRG と比べても, より低い電流密度で大きな出力 が得られていることがわかる。従って，本稿では $12 / 8$ PMRG が極数として最適であると判断した.

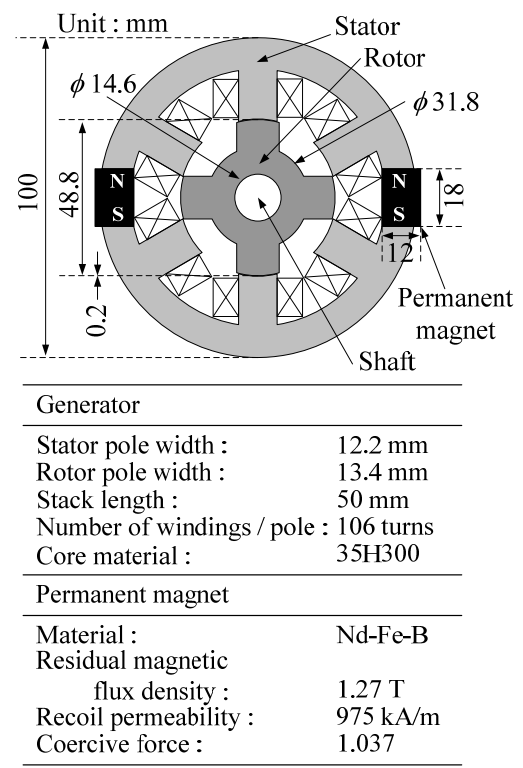

Fig. 1 Specifications of the 6/4 PMRG.

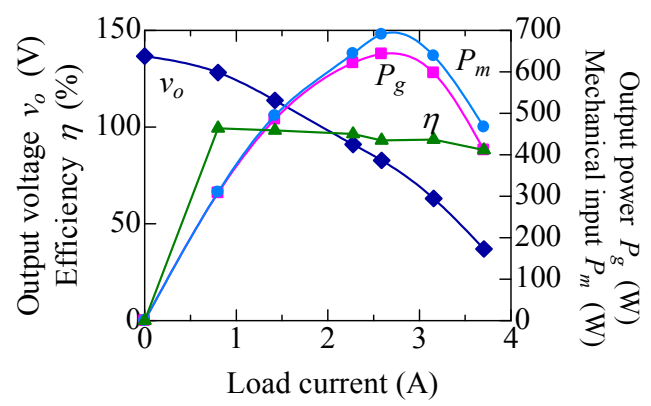

(a) Calculated values

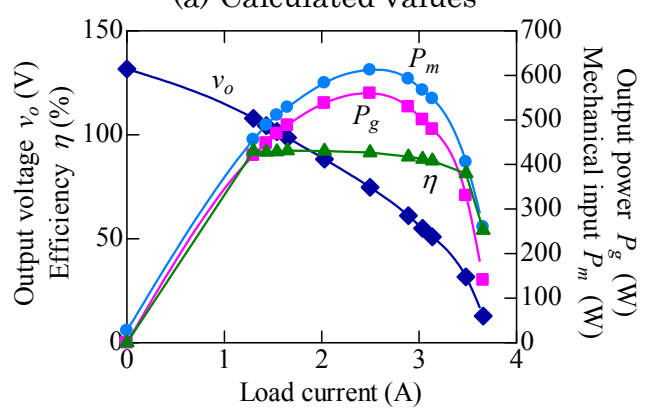

(b) Measured values

Fig. 2 Load characteristics of the 6/4 PMRG.
12/8 PMRG の細部の寸法については, 現有の 6/4 PMRG の寸法を基準にして決定した。具体的には，固定子ならび に回転子ともに極幅とヨーク幅の比は 6/4 PMRG と等しく し, ギャップ長や巻線の占積率も等しくした.

図 4 に，上述の考えに基づいて設計した $12 / 8$ PMRGの 諸元を示す. 直径は $180 \mathrm{~mm}$, 積み厚は多段積み構成とす ることから，1台当たりは $20 \mathrm{~mm}$ とした，従って，図 1 の 6/4 PMRG と比較して, 設計した $12 / 8$ PMRG はより扁平 な構造になっている。実際に用いる際には, 図 5 に示すよ うに, 同一形状の PMRG 3 台を 3 段に積み重ねるが, 各 PMRG で発生するトルクを $1 / 3$ 周期ずつずらし, 重畳させ てトルクリプルを抑制するため, 固定子はそれぞれ機械角 で 5 度ずつずらしている. 図 6 に，3 段積み PMRGのシス テム構成を示す. 各 PMRG の回転軸は同一であるため,

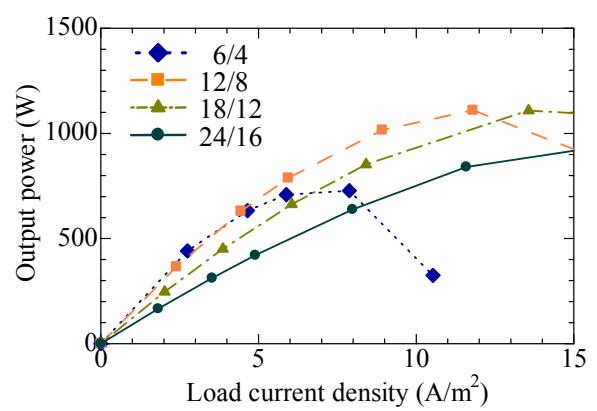

Fig. 3 Comparison of the output power of multipolar PMRGs.

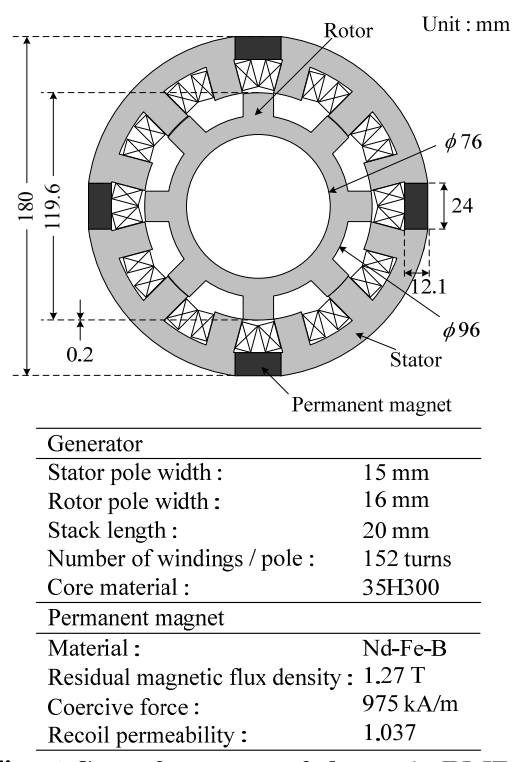

Fig. 4 Specifications of the 12/8 PMRG.

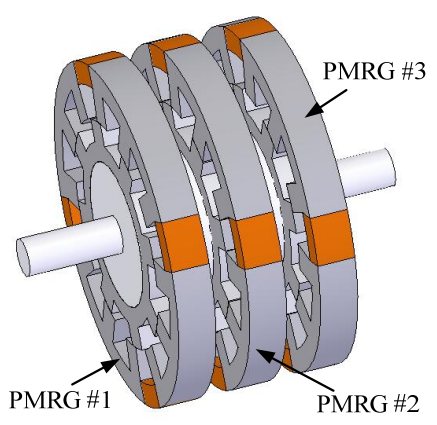

Fig. 5 Three-stacked 12/8 PMRG. 
発電機トルクは各々の PMRG の発生トルクの和になる.出 力側の回路は, それぞれのPMRGの出力を全波整流し, こ れらを並列に結線して, 平滑用のコンデンサ $C_{s}$ と負荷抵抗 に接続する構成とした.

図 7 に, 12/8 PMRGの 3D-FEM モデルを示す。計算機 容量および計算時間の削減のため, 3 段あるうちの 1 台分 をモデル化した。 また, 磁界の対称性を考慮して $1 / 8$ モデ ルを使用した。出力側の回路は, 図 8 に示すように各相の 巻線をスター結線し, ダイオードによる全波整流回路を介 して, 平滑用コンデンサ $C_{s}$ と負荷抵抗が接続されている.

図 9 に, 回転数 $1000 \mathrm{rpm}$ での 12/8 PMRG の発電特性 の計算值を示す. 3D-FEMにより算定された発電機の最大 出力は $158 \mathrm{~W}$ であった。 これに対して, 図 2 の結果に基づ き, 実機ではこの $88 \%$ に相当する $139 \mathrm{~W}$ 程度の出力が得 られると見積もると, 目標の定格出力 $133 \mathrm{~W}(=400 / 3 \mathrm{~W})$ を超えると予想される.

また, 図 5 に示したように, 同一形状の PMRGを 3 段 積みしたモデルを用いて, 最大出力点付近を 3D-FEM で解 析した結果, 1 段当たり $157 \mathrm{~W}$ の出力が得られたため, 多 段積みによる出力低下は無視できるほどわずかであること が確認できた.さらに, この点でのトルク波形を図 10 に 示す. この図を見ると, 各段のトルク波形は均等に位相が ずれており， 3 段積みすることでトルクリプルが半分以下 に抑制されることがわかる。

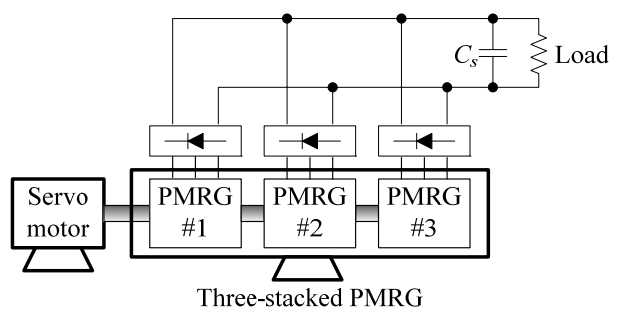

Fig. 6 System configuration of the three-stacked PMRG.

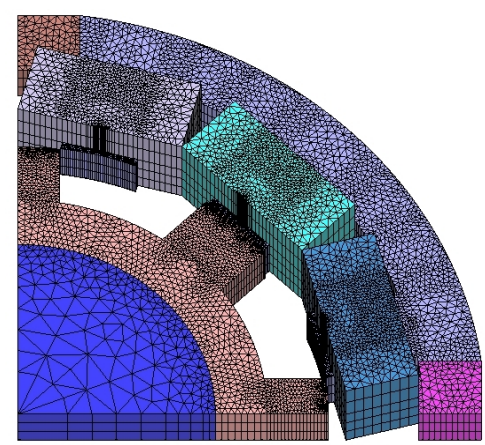

Fig. 7 3D-FEM model of the 12/8 PMRG.

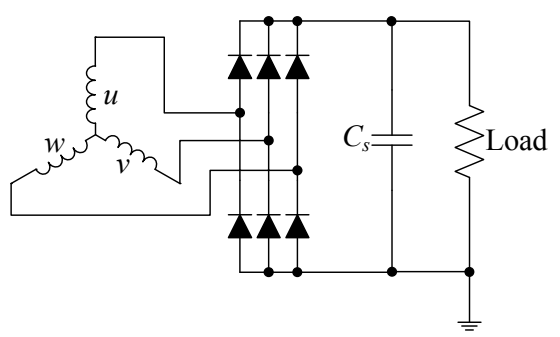

Fig. 8 Schematic diagram of an output circuit.

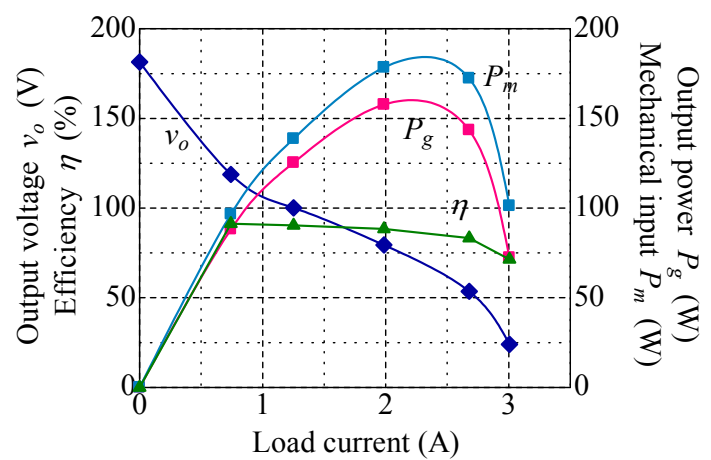

Fig. 9 Load characteristics of the 12/8 PMRG.

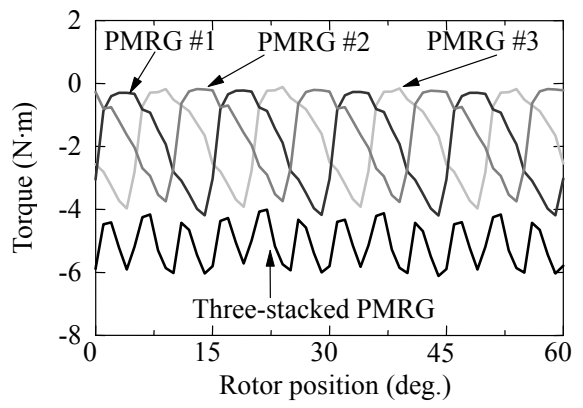

Fig. 10 Calculated torque waveforms at the maximum output.

\section{PMRG の基礎特性の試験結果}

前章での解析・設計に基づき，12/8 PMRGを試作し，基 礎特性の試験を行った. 図 11 に, 試作機とその実験システ ムの外観を示す. 12/8 PMRG はサーボモータによって, 任 意の回転数およびトルクで回転させることができる.また, サーボモータと PMRGの間には, トルク検出器を配置し, 入力トルクと回転数を測定する.なお，試作機は 3 段積み では無く，1段のみである.

まず初めに, 図 8 に示した回路は接続せずに, PMRGの 巻線の出力端を開放した状態で実験を行った. 図 12 に, PMRG の巻線に生じる誘起電圧波形を示す. 同図(a)が 3D-FEM による計算波形，(b)が観測波形である．回転数は $1000 \mathrm{rpm}$ である.これらの図を見ると, 振幅に多少の違 いはあるが両者はよく一致していることがわかる.

図 13 には, 速度対誘起電圧特性の計算值と実測值を示す. 図中の実線が計算值であり，実測值についてはすべての相 の誘起電圧をシンボルで示している。この図を見ると, 計 算值に対して実測值は $10 \%$ 程度小さくなっていることが わかる，また，実測された各相の誘起電圧は FEM と同様 に, 速度に比例して上昇していることもわかる.

次いで, 図 8 に示したように, 整流回路と平滑用コンデ ンサ，そして負荷を接続した構成で試験を行った。図 14 に最大出力時の電圧・電流の観測波形を示す. 電流波形を 見ると, 各相のバランスが多少崩れていることがわかるが, 整流後の波形はほぼ一定になっているので問題は無い.

図 15 に，回転数 $1000 \mathrm{rpm}$ で測定した $12 / 8$ PMRG の発 電特性を示す. 出力電力 $P_{g}$ の最大值は $125 \mathrm{~W}$ であり, そ のときの発電効率 $\eta$ は $83.7 \%$ \%った. 最大出力の目標值 は前章で述べたとおり，133 Wであったので，目標值を若 干下回る結果になった。 この要因としては, FEM による計 


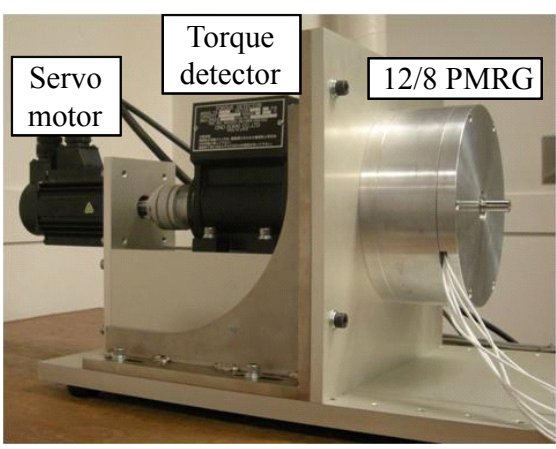

Fig. 11 Appearance of the experimental system of the 12/8 PMRG.

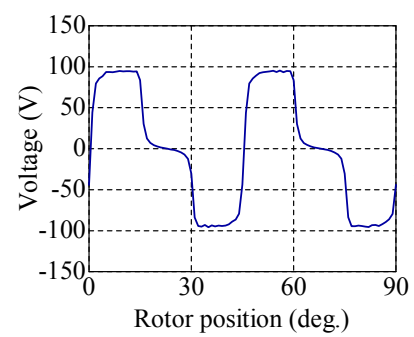

(a) Calculated waveform

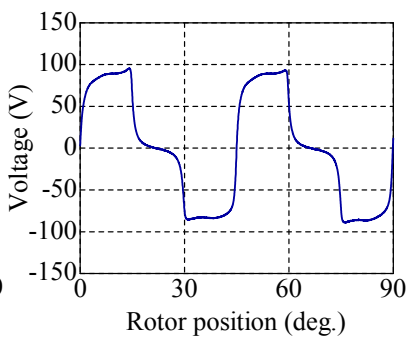

(b) Observed waveform
Fig. 12 Voltage waveforms at no-load.

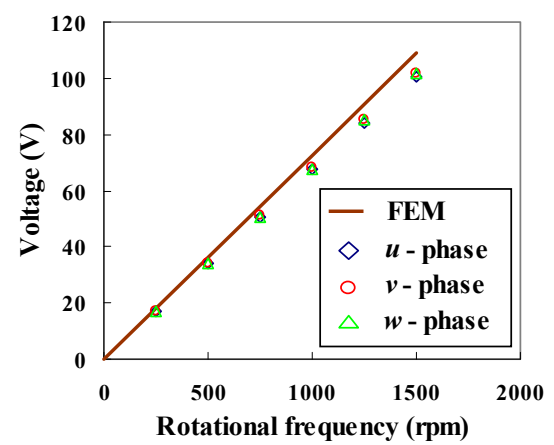

Fig. 13 Speed vs. induced voltage characteristics.

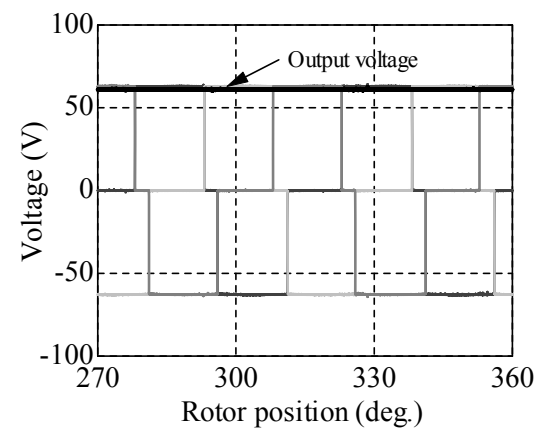

(a) Voltages

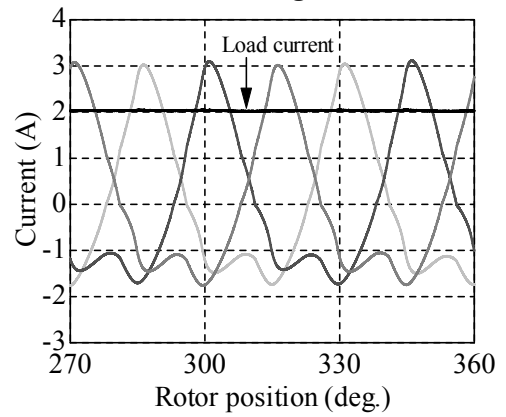

(b) Currents

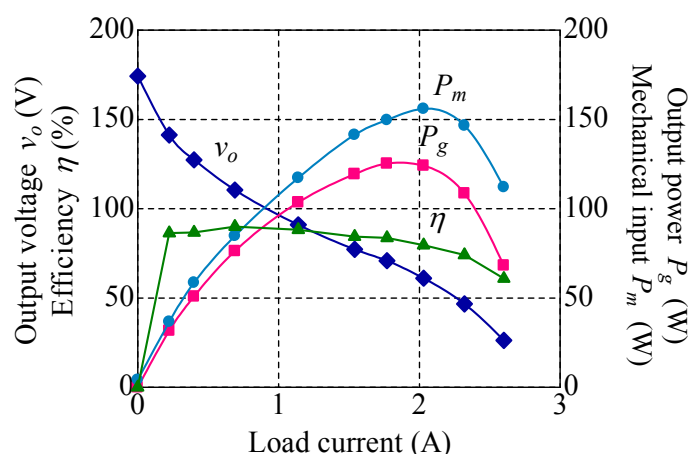

Fig. 15 Experimental result of load characteristics.

算值と実測值との誤差を正確に予測することは難しく，今 回参考にした 6/4 PMRGの場合と，12/8 PMRGの場合と では誤差の大きさに違いがあったことが挙げられる．6/4 PMRG では実機の最大出力が FEM の 88\%だったのに対し て，12/8 PMRG では 80\%であった．PMRG は固定子ヨー クに永久磁石を持つため, 巻線電流により生じる磁束が軸 方向へと漏れやすく，さらに，今回設計した $12 / 8 \mathrm{PMRG}$ は6/4 PMRGに比べてかなり扁平な形状であったことから, 軸方向への漏れ磁束が相対的に大きくなる．上記の漏れ磁 束を考慮するには，本稿の解析モデルでは軸方向の要素の 分割が若干粗かったため，これが誤差に影響したことが考 えられる。また，効率が 84\%程度しか得られなかったこと から, 今後はその原因と改善策について検討が必要である.

\section{4. まとめ}

本稿では， 3 段積みで定格 $400 \mathrm{~W}$ (1000 rpm）の 12/8 PMRG の設計を行うとともに，実機を試作して基礎特性の 試験を行った。 その結果, 試作した PMRG はほぼ目標通り の出力を有することが確かめられた，その一方で，今後は 効率改善に関する検討が必要であることが明らかになった. なお, 本研究の一部は科学研究費補助金基盤研究 (B)(19360125)の交付, ならびに福島県ハイテクプラザ公募 型新事業創出プロジェクト研究事業（新エネルギー用マイ クロ発電システムの開発）の補助を受けて行った.

\section{References}

1) A. V. Radun, C. A. Ferreira, and E. Richter: IEEE Trans. Ind. Applicat., 34, 1026 (1998).

2) F. M. El-Lithy and M. A. Elwany: Wind Engineering; 23, 269 (1999).

3) O. Ichinokura, J. Shida, K. Nakamura, and T. Watanabe: $J$. Magn. Soc. Jpn., 29, 571 (2005) (in Japanese).

4) O. Ichinokura, T. Ono, K. Nakamura, and T. Watanabe: $J$. Magn. Soc. Jpn., 30, 408 (2006) (in Japanese).

5) J. Yoshida, K. Nakamura and O. Ichinokura: The Papers of Technical Meeting on Magnetics, IEEJ, MAG-07-95 (2007) (in Japanese)

6) T. Tashiro, K. Nakamura, and O. Ichinokura: The Papers of Technical Meeting on Magnetics, IEEJ, MAG-06-112 (2006) (in Japanese).

2008 年 10 月 17 日受理, 2009 年 3 月 4 日採録

Fig. 14 Observed waveforms of output voltage and load current at the maximum output. 